\title{
THE MOTIVITY OF CHILDREN FROM A CHILDREN'S HOME TO EDUCATE
}

\author{
[MOTIVOVANOST DETI Z DETSKEHO DOMOVA KE \\ VZDELAVANI]
}

\section{Jana Kratka}

doi: 10.18355/PG.2020.9.2.1

\begin{abstract}
The paper describes institutional care in the Czech Republic with a subsequent focus on the children's home and the motivation of children educated in this facility. A historical overview of institutional care in the Czech Republic is presented. The aim is to present a research survey that found out how children educated in an children's homes are motivated to learn. A qualitative strategy was chosen, an anamnestic study using the interview method $(\mathrm{N}=20)$. The result shows that children are insufficiently motivated to learn by the children's home and the biological family. The results of studies are related to low motivation, which show that children from a children's home most often receive education at the level of a vocational school.
\end{abstract}

\section{Key words}

Education, institutional care, children's home, biological family, motivation

\begin{abstract}
Anotace
Příspěvek popisuje institucionální péči v České republice s následným zaměřením na dětský domov a motivaci dětí vzdělávaných $\mathrm{v}$ rámci tohoto zařízení. Je představen historický přehled institucionální péče $v$ České republice. Cílem je představit výzkumné šetření, které zjišstovalo, jak jsou děti vzdělávané $\mathrm{v}$ rámci dětského domova motivovány ke vzdělávání. Byla zvolena kvalitativní strategie, anamnestická studie s využitím metody rozhovoru $(\mathrm{N}=20)$. Výsledek ukazuje, že děti jsou nedostatečně motivovány ke vzdělávání dětským domovem i biologickou rodinou. S nízkou motivací souvisí výsledky studií, ze kterých vyplývá, že děti z dětského domova dosahují nejčastěji vzdělání na úrovni odborného učiliště.
\end{abstract}

\section{Klíčová slova}

Vzdělávání, institucionální péče, dětský domov, biologická rodina, motivace

\section{Úvod}

Hlavním cílem institucionální péče je zabezpečit dítě, jehož rodina je dysfunkční. Jedná se o nedílnou součást systému péče o dítě. $\mathrm{V}$ případě zjištění, že se rodina stala dysfunkční, zasahuje stát, který dítěti poskytne nejvhodnější formu náhradní péče. Mezi subjekty institucionální péče v České republice patří dětský domov, dětský domov se školou, diagnostický ústav a výchovný ústav. Tato zařízení lze také označit souhrnným pojmem 
rezidenční zařízení. Jedná se o ústavní zařízení, která poskytují jedinci komplexní péči, to znamená, že působí na jedince i v jeho vzdělávání (Buehler, 2000). Pobyt v institucionální péči s sebou nese také jistá rizika. Mezi ně patří např́iklad deprivační syndrom. Deprivace je ,,stav, kdy některá $z$ objektivně významných potřb není uspokojována $v$ dostatečné míre, přiměreným způsobem a po dostatečně dlouhou dobu“ (Vagnerova, 2014, p. 53). Matějček uvádí, že deprivace je stav psychiky, který vzniká následkem životních situací, kdy psychické potřeby dítěte či dospělého nejsou uspokojeny v dostačující míře (Langmeier, 2011). Následkem deprivačního syndromu je nestandardní vývoj dětské osobnosti, větší míra úzkostnosti. Čím dříve je dítě do ústavní výchovy umístěno a čím delší je čas pobytu, tím mohou být změny osobnosti trvalejší (Sebba, 2015). Dlouhodobý pobyt v ústavní výchově se promítá do budoucího života jedince, ovlivňuje jeho úspěšnost (Matejcek, 2015). Dalším rizikem je přizpůsobení se životu v instituci a následná neschopnost bezproblémového přechodu do samostatného života. Jedinec je v ústavní péči kompletně zaopatřen, což se jeví jako problém, protože následně není schopen adaptace na samostatnost. Je prokázané, že děti žijící v institucionální péči mají v dospělosti častější problémy ve společenském uplatnění (Siposova, 2000).

\section{Pozitivní charakteristické znaky institucionální péče v České republice}

Pazlarová (2017) shrnuje následující pozitivní znaky institucionální péče v České republice. Česká republika je státem se systémem péče s kvalitní sociální a právní ochranou o děti a mladistvé, $\mathrm{s}$ dostatečně rozvinutou sítí možností zajištění dítěte v nouzi. V praxi to znamená, že se nesetkáváme s dětmi, které by žily na ulici. Systém vzdělávání umožňuje vzdělání všem dětem a mladistvým. Závisí však na schopnostech a dovednostech dítěte. Institucionální péče v České republice prošla v posledních letech významnými změnami zaměřenými na zlepšení životních podmínek dětí a poskytované péče. Důraz je kladen na vytváření prostředí, které bude co nejvíce odpovídat životu v běžné rodině. Objevuje se úsilí neprodlužovat dobu pobytu v zařízení více, než je nezbytně nutné. Stále častěji dochází ke spolupráci s biologickými rodiči. Zároveň se zvyšuje úroveň vzdělání zaměstnanců podílejících se na vzdělávání dětí.

\section{Negativní charakteristické znaky institucionální péče v České republice}

Hlavním nedostatkem současného systému péče o dítě, je jeho roztř́šštěnost. Zařízení poskytující institucionální péči spadají pod jurisdikci tří ministerstev, a to Ministerstva práce a sociálních věcí, Ministerstva školství, mládeže a tělovýchovy a Ministerstva zdravotnictví. Výrazné snížení počtu dětí v institucionální péči nebude možné bez zlepšení prevence a podpory rodin. Česká republika se stále potýká s nízkým počtem pěstounských rodin, což je jednou z prríčin vysokého počtu dětí umístěných v rezidenční péči. Systém se nedostatečně specializuje na vytváření zařízení, která by poskytovala terapeutickou péči, především pro děti s psychickými poruchami. Slabinou systému je nedostatečná podpora jedinců po odchodu z ústavních zařizení při dosažení zletilosti. Většina zaměstnanců, 
poskytujících institucionální péči, jsou ženy. Chybí tak mužské vzory (Pazlarova, 2017).

\section{Kojenecký ústav}

Péče dětem ve věku od narození do tří let je poskytována kojeneckými ústavy. Jedná se o zdravotnické zařízení spadající pod jurisdikci Ministerstva zdravotnictví, které poskytuje zdravotní služby a zaopatření dítěte. Zařízení poskytuje komplexní zdravotní, výchovnou a sociální péči dětem a jejich matkám, které se ocitly $\mathrm{v}$ krizové situaci. Zařízení umistuje $\mathrm{v}$ žádoucích př́padech taktéž matky $\mathrm{s}$ dětmi. Indikacemi $\mathrm{k}$ tomuto pobytu může být zdravotní, diagnostická (závislost na omamných látkách, domácí násilí) nebo výchovná (zácvik gravidní ženy). Pro označení zařízení, které funguje na stejném principu, se využívá také název Dětské centrum (Hrubes, 2000). Česká republika je aktuálně jedinou zemí Evropské unie, která umist'uje děti od narození do některého z typů institucionální péče (Asociace proti plánu ministerstev měnit kojenecké ústavy od 2023, 2019).

\section{Dětský domov}

Dětský domov je zařízení, které je z pohledu veřejnosti nejznámějším poskytovatelem ústavní výchovy dětí v České republice. Do dětského domova jsou děti umistovány na základě rozhodnutí soudu, rozhodnutí o předběžném opatření. Dětský domov je určen pro děti ve věku od 3 do 18 let. $\mathrm{V}$ prípadě, že po dovršení plnoletosti jedinec ještě nemá ukončenou soustavnou př́pravu na povolání, dětský domov nabízí smlouvu o dobrovolném pobytu. Tato smlouva může být kdykoli ukončena, a to ze strany dětského domova i jedince. Důvodem může být porušení pravidel dětského domova, která pro jedince i nadále platí, přestože dosáhl plnoletosti. $\mathrm{V}$ praxi to znamená, že nejdéle lze $\mathrm{v}$ dětském domově setrvat do 26 let věku života. Jedná se o zařízení spadající pod jurisdikci Ministerstva školství, mládeže a tělovýchovy. Maximální kapacita jednoho dětského domova je čtyřicet osm dětí, děti žijí v rámci rodinných skupin. Každá rodinná skupina čítá šest až osm dětí. Sourozenci a blízcí příbuzní jsou umistováni na skupinu společně nehledě na věk či pohlaví, aby došlo k zachování rodinných vazeb. Péči na skupině zajištujuí dva vychovatelé, kteří se střídají. Noční služba je zajištována asistenty pedagoga. Cílem zařízení je poskytnout prostředí, které se co nejvíce podobá životu $v$ běžné rodině. Každodenní rozvrh se podobá rozvrhu dítěte žijícího v biologické rodině. Děti navštěvují školy dle jejich schopností, škola není součástí zařízení, což je hlavním rozdílem ve srovnání s dětským domovem se školou. Na rozdíl od dětského domova se školou, dětský domov nepřijímá děti se závažnými poruchami v chování. Po skončení vyučování se vrací zpět do dětského domova, kde se věnují prrípravě do školy. Mohou také navštěvovat kroužky či se věnovat oblíbeným aktivitám (Hajek, 2008).

\section{Př́ičiny umístění dítěte do dětského domova}

Důvodem pro umístění dítěte do dětského domova je situace, kdy se biologičtí rodiče o děti nechtějí, nemohou nebo neumí postarat. Konkrétními důvody pro umístění jsou zanedbávání péče o dítě, poruchy chování dítěte, 
závislostní chování na straně rodičů či dítěte a výchozí socioekonomické prostředí. Velmi často biologičtí rodiče čelí problémům, jako jsou psychická onemocnění a kriminální činnost s následným odnětím svobody. Jedním z neméně závažných důvodů je neplnění povinné školní docházky. V takových případech biologičtí rodiče nepřisuzují vzdělání patřičnou důležitost. Zanedbávání péče o dítě je nejčastějším důvodem pro umístění dítěte do rezidenční péče ve věku 0-6 let $(89 \%)$, u dětí ve věku 7-12 let se jedná zpravidla o poruchy chování $(83 \%)$, u pubescentů a adolescentů ve věku 13-16 jsou to v $57 \%$ nefunkční vztahy v biologické rodině (Rebelez, 2013).

\section{Dětský domov se školou}

Dětské domovy se školou jsou zařízení určená pro děti s poruchami chování nebo děti s mentálními poruchami. Zároveň je toto zařízení určené pro děti, které spáchaly trestný čin, nikoli však závažný. Jsou zde umístěny děti ve věku od šesti do patnácti let. Děti plní povinnou školní docházku v rámci zařízení. Režim je přísný, děti neopouští brány zařízení. Počet dětí je nižší oproti dětským domovům, na jedné skupině 5-8 dětí.

\section{Výchovný ústav}

Pro děti se závažnými poruchami chování jsou určeny výchovné ústavy. V zařízení pobývají adolescenti ve věku 15-18 let, kteří spáchali nějaký druh závažné trestné činnosti či trpí závažnou formou mentální poruchy. Zařízení je rozděleno na skupinu zaměřující se na závažnou trestnou činnost a skupinu zaměřující se na závažné mentální poruchy. Jen tak lze oběma skupinám poskytnout rozdílné př́stupy a potřeby. Výchovné ústavy pro dívky jsou oddělené od výchovných ústavi̊ pro chlapce. Maximální kapacita jednoho zařízení je čtyřicet osm dětí. Cílem je náprava či alespoň zmírnění již vzniklých problémů $\mathrm{v}$ chování. $\mathrm{V}$ rámci pobytu ve výchovném ústavu jsou děti také vzdělávány, nejčastěji se jedná o výuku odpovídající povinné školní docházce. Výchovné ústavy nabízí také vzdělání na úrovni středního vzdělání s výučním listem (Prucha, 2003).

\section{Diagnostický ústav}

Diagnostický ústav je zařízení, které poskytuje diagnostiku dítěte. Dítě do diagnostického ústavu zpravidla přichází přímo z biologické rodiny. Děti zde pobývají maximálně osm týdnů a jsou na skupinách rozděleny dle věku a pohlaví. Cílem ústavu je dítě nejen diagnostikovat, ale zároveň doporučit jeho další směřování. Diagnostické ústavy pro dívky jsou oddělené od diagnostických ústavi̊ pro chlapce. Pobytu $\mathrm{v}$ dětském domově zpravidla předchází právě diagnostický ústav (Matousek, 1998). V následující tabulce jsou uvedeny počty zařízení institucionální péče a dětí v ní umístěných ve školním roce 2018/2019. 


\begin{tabular}{|l|l|l|}
\hline Typ zařízení & Počet zařízení & Počet dětí \\
\hline Kojenecký ústav & 26 & 819 \\
\hline Diagnostický ústav & 13 & 394 \\
\hline Dětský domov & 138 & 4248 \\
\hline $\begin{array}{l}\text { Dětský domov se } \\
\text { školou }\end{array}$ & 28 & 759 \\
\hline Výchovný ústav & 25 & 993 \\
\hline Celkem & 230 & 7213 \\
\hline
\end{tabular}

Table 1: Počet zařízení institucionální péče a dětí v nich umístěných v České republice ve školním roce 2018/2019 ("Statistická ročenka školství: Zařízení pro výkon ústavní výchovy a ochranné výchovy”, 2019)

\section{Historický přehled institucionální péče v České republice}

Ochrana dětí a jejich práv v České republice prošla dlouhým historickým vývojem. První známky respektu vůči dětem zaznamenáváme v období šiřrení křest’anství. Veškerá péče, at’ už v rámci rodiny či mimo ni, byla vnímána optikou dospělého člověka. Situace se začala měnit s příchodem osvícenství, které začalo dětství věnovat výraznější pozornost. S příchodem průmyslové revoluce se však opět situace mění k horšímu. Děti z nižší sociální vrstvy jsou nuceny se zapojit do pracovního procesu, který negativně působí na jejich zdraví. Právo dětí na péči a jejich ochranu bylo plně prijjato až ve 20 . století. Jako zlom v Evropě lze považovat období nastalé po první světové válce, tedy po roce 1918 . V této době byl zaveden centralizovaný systém péče o opuštěné děti. Upřednostňovala se podoba dnešní pěstounské péče. Ve větších zařízeních byl maximální počet 20 dětí v zařízení, pro srovnání je v současnosti tento počet 48 dětí. Na základě údajů z roku 1931 bylo s ohledem na celé území Československa 24 dětských domovi̊ pro děti mladšího věku a 60 dětských domovi̊ pro starší děti (Matejcek, 1999).

Dalším stěžejním je rok 1959, který přinesl deklaraci Organizace spojených národů, zaměřujících se na práva dětí. Vyvrcholením o úsilí o ochranu dětí a jejich práv př̀išlo v roce 1989 s Úmluvou o právech dítěte, která byla ratifikována Českou a Slovenskou federativní republikou v roce 1991. Úmluva o právech dítěte je součástí českého právního systému a poskytuje rámec pro právní předpisy v oblasti sociálně-právní ochrany dětí (Bubleova, 2000).

Nejstarší formou o opuštěné děti na našem území byly středověké sirotčince, jejich zřizovatelem byly kláštery. Od 18 . století začaly vznikat sekulární sirotčince, které spravovalo město. $\mathrm{V}$ této době byla typická vysoká úmrtnost v dětském věku, celkové podmínky nebyly pro děti vyhovující. $V$ těchto počátcích byla dětem poskytována pouze péče, která primárně bojovala $\mathrm{o}$ jejich přežití. Až s pokrokem vědy, na počátku 19. století přichází změny v péči o opuštěné děti, které se zaměřovaly i na výchovu dětí. Jako forma profesionální péče o děti byly zř́zeny první typy institucionální péče v Rakousku-Uhersku. Zařízení byla určena nejen pro sirotky, ale i děti se zdravotním či jiným postižením. Velká změna nastala zejména po roce 1948, 
kdy se moci ujala komunistická strana. V souladu se svými ideologickými názory preferoval režim kolektivní vzdělávání. Tento princip byl aplikován na všechny oblasti vzdělávání, nejen na péči o děti bez rodin. Nejdramatičtějším opatřením mezi těmito změnami bylo plošné zrušení rodinné pěstounské péče $\mathrm{v}$ roce 1950 (Bubleova, 2000). Pěstouni byli nuceni tyto děti vrátit do dětských domovů, což mělo za následek, že prakticky přes noc byly tisíce dětí odvezeny z rodin a umístěny do dětských domovi̊. Byly vytvořeny desítky nových dětských domovů s kapacitou často přesahující sto dětí (Matejcek, 1999).

Za stěžejní osobnosti, které se v roce 1963 podílely na obnovení pěstounské péče, patř́ Zdeněk Matějček, Jiř́ Dunovský a Josef Langmeier. Zároveň je důležité podotknout, že právě tito autoři poskytli ucelená knižní díla a odborná periodika zaměřující se na toto téma $\mathrm{v}$ českém prostředí. Dětské domovy však stále existovaly a jednalo se o dětské domovy internátního typu, což znamená, že děti byly rozděleny dle věku a pohlaví. Prvotním záměrem bylo poskytnout nejlepší dostupnou péči a vzdělání dětem. Je však vědecky dokázáno, že tento druh kolektivního vzdělávání měl na děti dlouhodobě negativní dopady. Na tuto skutečnost upozorňoval právě Langmeier $\mathrm{s}$ Matějčkem. $\mathrm{K}$ dalším systémovým změnám $\mathrm{v}$ péči o tyto děti začalo docházet až po obnovení demokracie v České republice v roce 1989 (Langmeier, 2011).

\section{Vzdělávání dětí v rámci institucionální péče}

Zvyšuje se pozornost směřující $\mathrm{k}$ rezidenční péči, především ke zlepšení standardů v péči o zdraví dětí (Saunders, 1997) a kontaktu s členy biologické rodiny. Další oblast, které se věnuje pozornost, je vzdělávání dětí v institucionální péči (Marsh, 1998). Všechny děti potřebují stabilní a podpůrné prostředí, potřeby dětí vyrůstajících $\mathrm{v}$ institucionální péči jsou odlišné od potřeb dětí žijících $\mathrm{v}$ biologických rodinách. Cílem školských zařízení je zaměření se na podporu, kterou lze poskytnout $\mathrm{v}$ rámci školy tím, že nejprve určí jedinečné potřeby žáků a vhodné prostředky, kterými budou moci tyto potřeby naplnit (Rebelez, 2013).

Výzkumy dokládají propast mezi vzdělávacími výsledky dětí v rezidenční péči a jejich vrstevníky $\mathrm{v}$ biologických rodinách $\mathrm{v}$ různých geografických částech světa. Výzkumy také dokumentují, že u dětí, které žijí $\mathrm{v}$ institucionální péči, existuje vyšší pravděpodobnost, že se u nich objeví psychické problémy, vyšší pravděpodobnost, že nebudou přijati na požadovanou školu a až tři a půl krát vyšší pravděpodobnost, že se u nich projeví speciální vzdělávací potřeby. Je třeba vzít v úvahu sociální a emocionální potřeby, protože vytvářejí základ pro blaho žáků (Landsverk, 2009).

Přehled výzkumů Goddarda (2000) ukazuje, že 75\% jedinců, kteří prošli nějakou z forem institucionální péče, nedosáhlo žádné kvalifikace. Děti, které vstupují do rezidenční péče ve vyšším věku, dosáhly horších vzdělávacích výsledků a pokroků než ti, kteří byli umístěni v raném věku (Sebba, 2015). Důležité je taktéž zapojení biologických rodičů do péče o děti. Zájem rodičů hraje důležitou roli ve školním úspěchu dětí. Za spolupracující rodinu lze označit rodiče, kteří své dítě navštěvují minimálně v měsíčních intervalech. 
Převažují však rodiče, kteří své děti nejen nenavštěvují, ale ani nekontaktují. Pokud ke kontaktu dochází, nejčastěji je to s matkou, výjimečně se stává, že by dítě bylo ve stejnoměrném kontaktu s oběma rodiči. Časté bývají kontakty s prarodiči, kteří se snaží o zachování vazby na rodinu. Zapojení biologické rodiny do vzdělávání dětí (např. pomoc př̌i zpracování domácích úkolů) je spojeno s lepšími studijními výsledky (Dill, 2012; Jackson, 2002).

Údaje zahraniční potvrzují i zdroje české. Z údajů Ministerstva školství, mládeže a tělovýchovy České republiky vyplývá, že celkem $30 \%$ jedinců vyrůstajících $\mathrm{v}$ rámci institucionální péče dosáhlo pouze základního vzdělání. Nejvyšší podíl jedinců absolvovalo studium na odborné škole, zakončené získáním výučního listu. Podíl vysokoškoláků činí $2 \%$, což z celkového počtu 4270 klientů dětských domovi̊ činí 66 studentů (Statistická ročenka školství: MŠMT).

\begin{tabular}{|l|l|}
\hline $\begin{array}{l}\text { Počet dětí (mládeže) v dětském domově } \\
\text { v České republice (2017/2018) }\end{array}$ & \\
\hline Celkem & 4262 \\
\hline Dívky & 1987 \\
\hline Chlapci & 2275 \\
\hline Úplní sirotci & 33 \\
\hline Před zahájením povinné školní docházky & 450 \\
\hline Plnící povinnou školní docházku & 2646 \\
\hline
\end{tabular}

Table 2: Počet dětí (mládeže) v dětském domově v České republice 2017/2018 (Statistická ročenka školství: MŠMT [Online]. http://toiler.uiv.cz/rocenka/rocenka.asp)

\section{Vzdělávání dětí z dětského domova}

„Dětský domov je výchovné zařizení pro ústavni výchovu dětí. Zajištuje výchovnou, hmotnou a sociálni péči dětem, které nemohou být osvojeny nebo umistěny v jiné formě rodinné péče. Pečuje o děti zpravidla od 3 do 18 let, popřipadè do ukončení prípravy na povoláni. “ (Hajek, 2008, p. 149)

Období, kdy je jedinec vzděláván, je považováno za stěžejní pro další životní úspěchy, obzvláště u dětí, které vyrůstají mimo biologickou rodinu a jsou vzdělávány $\mathrm{v}$ rámci institucionální péče (Martin, 2002). Dle dostupných výzkumů dospělí jedinci, kteří prožili své dětství $\mathrm{v}$ rámci některého ze zařízení ústavní výchovy, prokazatelně dosáhli nižšího vzdělání a byli ve studiu méně podporováni (Myskova, 2015; Langmeier, 2011; Stancikova, 1991; Skoviera, 2007). Nižší dosahované vzdělání jedinců vzdělávaných $\mathrm{v}$ rámci dětského domova oproti vrstevníkům $\mathrm{z}$ funkčních rodin souvisí 
taktéž s jejich nižší mentální úrovní, kterou ovlivňuje nejen výchozí prostředí, ale i následná nízká motivace jak ze strany biologické rodiny, tak i vychovatelů $\mathrm{v}$ dětském domově. Tato skutečnost je potvrzena výzkumy (Stancikova, 1991; Vagnerova, 2004).

Děti z dětského domova jsou vzdělávány v běžných školách. Děti, které jsou žáky základní školy, zpravidla docházejí na základní školu, která je v místě sídla dětského domova. To znamená, že koncentrace dětí z dětských domovi̊ ve školách není $\mathrm{v}$ republice rovnoměrná. Výběr dalšího studia po ukončení povinné školní docházky závisí především na schopnostech či zájmech dítěte (Skoviera, 2007). Děti žijící v dětském domově se vyznačují mnohdy problémovým chováním (Vavrova, 2015; Bendl, 2016). Důvodem může být snaha upoutat na sebe pozornost, která jedinci v biologické rodině chyběla anebo nedostatek žádoucích sociálních návyků. Dochází tím však $\mathrm{k}$ narušování výuky a tím i k zvýšeným nárokům na učitele. Důležité tedy je, aby učitel ke každému dítěti přistupoval zcela individuálně (Martin, 2002).

Učitel může výrazně přispět svým př́ístupem ke kladnému vztahu žáka $\mathrm{k}$ učivu. Pravidelný kontakt mezi učitelem a vychovatelem je důležitý. Jen tak lze dosáhnout plné informovanosti o dítěti. Je třeba umět dítě pochválit, a to i za maličkosti (Helms, 1996). Schopnost ocenit dítě může vést ke zlepšení jeho postoje $\mathrm{k}$ př́ípravě na vyučování a následnému zlepšení jeho prospěchu (Jackson, 2006). Děti z dětského domova mohou být také vzdělávány ve speciálních školách. Důvodem může být nižší intelekt. V takových prŕípadech děti o vzdělávání nejeví dostatečný zájem, a proto je mnohem těžší je motivovat (Komarkova, 2009).

Vývoj dítěte i jeho vzdělání může podpořit př́stup dětského domova, který ovlivňuje rozhodnutí jedince o budoucím povolání. Postoje ke vzdělání se utváŕí v průběhu života pod vlivem okolí a vlastních zkušeností. Následně pak tyto postoje ovlivňují další studijní motivaci a výkony (Burda, 2003). Důvodem neschopnosti prijímat pochvaly a motivaci ze strany druhé osoby může být nedostatečná sebejistota a nedůvěrivost, která také může souviset s nižším sebepojetím (Matejcek, 1994). Snahou dětského domova je připravit vzdělaného, samostatného jedince, schopného vést plnohodnotný život (Bartonova, 2011).

\section{Výzkumné šetření}

Cílem výzkumného šetření bylo zjistit, zda jsou děti během života $v$ dětském domově ke studiu nějakou formou motivovány, zda dochází k motivaci ze strany biologické rodiny či dětského domova. Respondenti popisují, jak motivaci rozumí a co vše za motivaci považují. Sběr dat byl založen na individuálním rozhovoru s respondenty, kteři v institucionální péči strávili minimálně pět let. Výzkumné šetření bylo zaměřeno na zodpovězení následující výzkumné otázky:

Jakou formou jsi byl/a motivován/a ke studiu dětským domovem a biologickou rodinou?

\section{Metodologie}

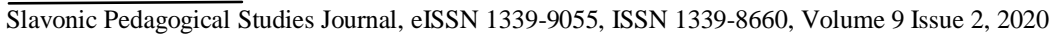


Výzkumný soubor tvořily osoby, které během dětství strávily nejméně pět let $\mathrm{v}$ dětském domově. Zkušenosti $\mathrm{s}$ různými typy péče se $\mathrm{v}$ jednotlivých př́ípadech kombinují. Většina respondentů z výzkumné skupiny žila určitou dobu ve své původní rodině, odkud přecházeli do institucionální péče. Výzkumná skupina byla oslovena prostř̌ednictvím dětského domova, který zůstává s některými jedinci v kontaktu i po jejich odchodu. Nebyla stanovena konkrétní kritéria pro výběr respondentů, jako je vzdělanostní úroveň respondentů nebo socioekonomický status. Také byla použita technika snowball, kdy někteří respondenti poskytli kontakt na jiné již bývalé klienty dětského domova. Zkoumanou skupinu tvořilo dvacet respondentů, deset mužů a deset žen, průměrný věk respondentů činil dvacet devět let. Jednalo se o respondenty, kteří byli klienty celkem pěti dětských domovů. Výzkum využíval kvalitativní metodologii, metodou sběru dat byl polostrukturovaný rozhovor. Všechny rozhovory byly analyzovány za pomocí kvalitativních postupů, zejména narativní a diskurzivní analýzy, konkrétně otevřeným kódováním. Jednalo se o retrospektivní výzkumné šetření, které probíhalo v období od března 2019 do září 2019.

\section{Výsledky}

Převážná většina dětí z dětského domova není motivována ke vzdělávání jejich biologickou rodinou, což uvedlo celkem šestnáct respondentů $\mathrm{z}$ dvaceti. Ve všech těchto prŕpadech nedošlo téměř $\mathrm{k}$ žádnému osobnímu kontaktu. Dětský domov je však spíše motivujícím prostředím pro vzdělávání dětí, jak uvádí dvanáct respondentů z dvaceti. Je však třeba poznamenat, že navzdory úsilí pedagogů a zaměstnanců dětského domova mohou být děti jasně demotivovány, například ostatními dětmi žijíími v dětském domově, jejichž výsledky jsou podprůměrné (Islam, 2017). Motivace dětského domova také nefunguje př́iliš často, protože je prezentována autoritářsky a dítě ji nepřijímá (Martin, 2002).

$Z$ celkového počtu dvaceti respondentů celkem šestnáct $(40 \%)$ z nich vypovědělo, že nebyli ke studiu motivováni biologickou rodinou. Tím důvodem je především fakt, že biologičtí rodiče vzdělání a motivaci nepovažují za důležité nebo nedochází k žádnému kontaktu. Jen čtyři (10 \%) probandi byli motivováni ke studiu rodinou. Celkem dvanáct (30\%) dotázaných uvedlo, že ke studiu byli motivováni dětským domovem, osm $(20$ \%) respondentů nemělo pocit, že by je dětský domov nějakou formou ke studiu motivoval.

\section{Závěr}

Respondenti si pod pojmem motivace ke studiu představují nějakou odměnu, dar v podobě sladkosti či nějakého hodnotného dárku. Pouze dva z respondentů vnímali jako motivaci při studiu psychickou podporu, tedy pochvalu, pohlazení, a především pomoc při školní prrípravě. Příprava do školy probíhala téměř vždy hromadně, a to nejčastěji ihned po př́chodu ze školy a zpravidla byla založena na samostatnosti dětí. Vychovatel byl $\mathrm{k}$ dispozici, aby mohl dětem pomoci. Většina respondentů v rozhovoru ale zmiňovala, že se jen zřídka snažili využít nabídku pomoci od vychovatele. Iniciativa musela vyjít od nich. Nedostatečná školní př́prava se jednoznačně 
podílí na nižší vzdělanostní úrovni. S tou následně souvisí horší uplatnění na trhu práce a nižší životní úroveň (Jackson, 2006). Získané výsledky inspirují k dalším otázkám a výzkumům, např. jak zvýšit motivovanost dětí, jak mohou efektivněji pomoci učitelé ve škole a jaké jsou možnosti a omezení spolupráce vychovatelů $\mathrm{z}$ dětských domovů a učitelů na základních školách.

\section{Bibliographic references}

ASOCIACE PROTI PLANU MINISTERSTEV MENIT KOJENECKE USTAVY OD 2023. 2019. Ceske noviny. Praha: CTK, 10.07.2019. Available online: https://www.ceskenoviny.cz/zpravy/asociace-proti-planuministerstev-menit-kojenecke-ustavy-od-2023/1776322

BARTONOVA, M. - VITKOVA, M. 2011. Vzdelavani zaku se specialnimi vzdelavacimi potrebami V.: Education of pupils with special educational needs V. Brno: Paido. ISBN 978-80-7315-220-8.

BENDL, S. - HANUSOVA, J. - LINKOVA, M. 2016. Zak s problemovym chovanim: cesta institucionalni pomoci. Praha: Stanislav Juhanak - Triton. ISBN 978-80-7387-703-3.

BUBLEOVA, V. 2000. Historicky vyvoj pece o opustene deti. Nahradni rodinna pece. vol. 1, pp. 49-50.

BUEHLER, C. - ORME, J. - POST, J. - PATTERSON, D. A. 2000. The long-term correlates of family foster care. Children and Youth Services Review. DOI: 10.1016/ S0190-7409(00)00108-0.

BURDA, V. - FESTOVA, J. - UlOVCOVA, H. -VOJTECH, J. 2003. Pristup mladych lidi ke vzdelavani a jejich profesni uplatneni: Projekt programu LS „Vyzkum pro statni spravu“ Ministerstva skolstvi, mladeze a telovychovy. Praha: NARODNI USTAV ODBORNEHO VZDELAVANI. Available online: http://www.nuov.cz/uploads/Vzdelavani_a_TP/Pristup_cele_konecnezneni.p df

DILL, K. - FLYNN, R. J. - HOLLINGSHEAD, M. - FERNANDES, A. 2012. Improving the educational achievement of young people in out-ofhome care. Children and Youth Services Review. vol. 34, n. 6, 1081-1083. DOI: $10.1016 /$ j.childyouth.2012.01.031. ISSN 01907409. Available online: https://linkinghub.elsevier.com/retrieve/pii/S0190740912000540

GODDARD, J. 2000. The education of looked after children. Family Social Work. vol. 5, n. 1, pp. 79-86. DOI: 10.1046/j.1365-2206.2000.00143.x. ISSN 1356-7500. Available online: http://doi.wiley.com/10.1046/j.13652206.2000.00143.x

HAJEK, B. - HOFBAUER, B. - PAVKOVA, J. 2008. Pedagogicke ovlivnovani volneho casu: soucasne trendy. Praha: Portal. ISBN 978-807367-473-1.

HELMS, W. 1996. Lepe motivovat - mene se rozcilovat: jak pomahat detem se skolou. Prelozil Jitka VRATILOVA. Praha: Portal. Uceni v pohode. ISBN 80-7178-087-1.

HRUBES, J. 2000. Kojenecky ustav v Krci. Vecernik Praha. vol.10, n. 29, 21 p. 
ISLAM, T. - FULCHER, L. 2017. Residential child and youth care in a developing world: European perspectives. Cape Town: The CYC-Net Press. ISBN 978-1-928212-28-7.

JACKSON, S. 2006. Educating Children in Residential and Foster Care. Oxford Review of Education. vol. 20, n. 3, pp. 267-279. DOI: 10.1080/0305498940200301. ISSN 0305-4985. Available online: http://www.tandfonline.com/doi/full/10.1080/0305498940200301

KOMARKOVA, T. 2009. Deti z detskych domovu na ZS: 3 pohledy. Rodina a skola. Rodina a skola. Praha: SPN, vol. 56, n. 4, pp. 6-7. ISSN 0035-7766.

LANDSVERK, J. - BURNS, B. - STAMBAUGH, L. - ROLLS REUTZ, J. 2009. Psychosocial interventions for children and adolescents in foster care: Review of research literature. Child Welfare. vol. 88, n. 1, pp. 49-69.

LANGMEIER, J. - MATEJCEK, Z. 2011. Psychicka deprivace v detstvi. Praha: Karolinum. ISBN 978-80-246-1983-5.

MATEJCEK, Z. 1994. O rodine vlastni, nevlastni a nahradni. Praha: Portal. Radci pro rodice a vychovatele. ISBN 80-85282-83-6.

MATEJCEK, Z. - DYTRYCH, Z. 1999. Nevlastni rodice a nevlastni deti. Praha: Grada, 144 p. ISBN 80-7169-897-0.

MATEJCEK, Z. 2015. Co deti nejvic potrebuji. Vyd. 7. Praha: Portal. ISBN 978-80-262-0853-2.

MATOUSEK, O - KROFTOVA, A. 1998. Mladez a delikvence: [mozne priciny, soucasna struktura, programy prevence kriminality mladeze]. Praha: Portal. ISBN 80-7178-226-2.

MARSH, P. 1998. Leaving care and extended families. Adoption and Fostering. vol. 22, pp. 6-14.

MARTIN, P. Y. - JACKSON, S. 2002. Educational success for children in public care: advice from a group of high achievers. Child \& Family Social Work. vol. 7, n. 2, pp. 121-130. DOI: 10.1046/j.1365-2206.2002.00240.x. ISSN 13567500. Available online: http://doi.wiley.com/10.1046/j.13652206.2002.00240.x

MYSKOVA, L. - SMETACKOVA, I. - NOVOTNA, H. - ONDER, J. KUZELOVA, H. - PTACEK, R. 2015. Vzdelani u osob se zkusenosti s nahradni formou pece $\mathrm{v}$ detstvi. Pedagogicka orientace [online]. 25(1), 63-83. DOI: $10.5817 /$ PedOr2015-1-63. ISSN 1805-9511. Available online: https://journals.muni.cz/pedor/article/view/2986

PAZLAROVA, H. 2017. Residential Child and Youth Care Practices in the Czech Republic. ISLAM, T. a L. FULCHER. Residential child and youth care in a developing world: European perspectives. Cape Town: The CYCNet Press, pp. 205-218. ISBN 978-1-928212-28-7.

PRUCHA, J. - MARES, J. - WALTEROVA, E. 2003. Pedagogicky slovnik. 4. aktualiz. vyd. Praha: Portal. ISBN 80-7178-772-8.

REBELEZ, J. L. 2013. Serving foster youth in the school setting: Ethical considerations. School Psychology: From Science to Practice. vol. 6, n. 1, pp. $19-26$.

SAUNDERS, L. - BROAD, B. 1997. The Health Needs of Young People Leaving Care. Leicester: De Montfort University.

SEBBA, J. - BERRIDGE, D. -LUKE, N. - FLETCHER, J. - K. BELL, K. STRAND, S. - O'HIGGINS, A. 2015. The educational progress of looked 
after children in England: Linking care and educational data. Oxford: Rees Centre.

STANCIKOVA, J. 1991. Intelektove vykony a skolska uspesnost chovancov detskych domovov. Specialni pedagogika. vol. 1. n. 4, pp. 171-181.

STATISTICKA ROCENKA SKOLSTVI: MSMT. Kapitola: Zarizeni pro vykon ustavni a ochranne vychovy: Rok 2016/2017. Available online: http://toiler.uiv.cz/rocenka/rocenka.asp

STATISTICKA ROCENKA SKOLSTVI: ZARIZENI PRO VYKON USTAVNI VYCHOVY A OCHRANNE VYCHOVY, 2019. Ministerstvo skolstvi, mladeze a telovychovy. Available online: http://toiler.uiv.cz/rocenka/rocenka.asp

SIPOSOVA, M. 2000. Legislativny pohlad na sucasny problem deti odchadzajucich $\mathrm{z}$ institucionalnej vychovy. Humanita: casopis dobrovolnickeho sektora Slovenskej republiky. pp. 1-3. ISSN 1336-2208.

SKOVIERA, A. 2007. Dilemata nahradni vychovy: [teorie a praxe vychovne pece o deti v rodine a v detskych domovech]. Praha: Portal. ISBN 978-807367-318-5.

VAGNEROVA, M. 2004. Zaklady psychologie. Praha: Karolinum, 358 p. ISBN 80-246-0841-3.

VAGNEROVA, M. 2014. Soucasna psychopatologie pro pomahajici profese. Praha: Portal. ISBN 978-80-262-0696-5.

VAVROVA, S. 2015. Children and Minors in Institutional Care: Research of Self-Regulation. Procedia - Social and Behavioral Sciences. vol. 171, pp. 1434-1441. DOI: 10.1016/j.sbspro.2015.01.265. ISSN 18770428. https://linkinghub.elsevier.com/retrieve/pii/S1877042815002955

Mgr. Jana Kratka

Department of Pre-primary and Primary Education

Charles University in Prague

Magdaleny Rettigove 4

Praha 111639

Czech Republic

jana.kratka@pedf.cuni.cz 